\title{
Non-microbiological turbidity of beer: Part 1 - semireview
}

\author{
Jana Olšovská*, Lucie Kyselová, Petra Kubizniaková, Martin Slabý \\ Research Institute of Brewing and Malting, Lípová 511/15, \\ 120 00, Prague 2, Czech Republic corresponding author: olsovska@beerresearch.cz
}

\begin{abstract}
Beer is a complex mixture consisting of hundreds of chemical substances. Some of them are macromolecules, such as proteins and polysaccharides that together with polyphenolic compounds form poorly soluble complexes causing beer turbidity or cold colloidal turbidity. Furthermore, beer turbidity can be caused also by procedural particles entering into beer during brewing process (filtration and stabilization aids) or by foreign particles from external environment (mechanical impurities). If turbidity, sediment or individual particles occur in filtered and stabilized beer, their origin must be determined since brilliant visual impression of the filtered beer influences an opinion of customers on a specific product. The identification of different species of turbidity using microscopic image, particle staining, enzymatic analysis or identification precursors is clearly described in this paper. The study includes pictorial documentation of various particles that may be part of beer turbidity.
\end{abstract}

Keywords: beer, colloidal turbidity, protein turbidity, protein-polyphenol turbidity, haze, microscopic analysis, image analysis, particle identification

\section{Introduction}

Turbidity in filtered and stabilized beer is still considered as a serious sensory defect of quality in spite of the expansion of products designed as hazy beers (e.g. NEIPA, wheat beer, cellar beer, or craft beer that undergo only minimal treatment after fermentation). The beer instability manifested as turbidity, haze, or opacities needs to be constantly explored. The identification of turbidity is essential for brewers because it is the key to understanding the causes of its occurrence and thus it presents a possibility to prevent its formation. Nowadays, the majority of industrial breweries filter and stabilize beer to keep it clear through the whole guarantee period. Nevertheless, beer is a "living organism" which changes its properties in time. Therefore, turbidity or sediment may appear in a beer despite careful treatment. Turbidity of beer may occur immediately after bottling or pasteurization, also during transport, or may be formed later during storage.

Generally, turbidity is understood as cloudiness or haziness of a liquid that is caused by a large number of diverse particles (DIN EN ISO 7027-1, 2016). Turbidity lies not only in the number of particles but it also depends on the particle size and composition (Kahle et al., 2020a). Beer turbidity can be detected by the naked eye or using several analytical or microscopic methods that enable not only to characterize visual opacities but also identify the so-called invisible haze.

We can generally distinguish turbidity of a microbiological origin i.e., caused by the action of undesirable microorganisms; and of a non-microbiological (physical-chemical, colloidal) nature - i.e., of various composition and origins, without the contribution of microorganisms.

The aim of this work is to offer a practical guide through such a complex issue which beer turbidity presents, and at the same time to summarize several procedures enabling the identification of turbidity-forming particles. As the set of results is very large, we decided to split the article into two parts. This first part summarizes 
the theory and shows examples of common turbidity. The second part presents interesting and sometimes very unexpected examples from practice.

\section{Physical-chemical and/or colloidal instability}

Undissolved solids of different compositions and origins cause non-microbiological turbidity due to light scattering (Kahle et al., 2020a). This is a highly complex phenomenon in which factors such as interparticle interaction, thermodynamic aspect, $\mathrm{pH}$, or microstructure are involved (Chhabra and Basavaraj, 2019). The size of particles constituting turbidity is various, from $1 \mathrm{~nm}$ to the eye visible (Kahle et al., 2020a). Thus coarsely or molecularly dispersed solids can be observed in beer as a result of the so-called Tyndall effect (Kahle et al., 2020a).

\subsection{Particle size}

Turbidity is formed by suspended insoluble particles of colloidal or larger size. Physicists talk about colloidal dispersion as a basic mixture type that is formed by particles ranging between $1 \mathrm{~nm}$ to $1 \mu \mathrm{m}$ in diameter. The particles should remain dispersed and do not settle at the bottom of the vessel. On the contrary, particles larger than $1 \mu \mathrm{m}$ form suspension because they usually settle out and do not form a stable system (Chhabra and Basavaraj, 2019).

Colloidal dispersion is regarded as stable if the particles remain single units and do not associate together forming clusters and aggregates. In other words, particles either must be of a density similar to the maternal liquid or sufficiently small for the ambient energy to keep them suspended (Siebert, 2009).

However, beer is a solution containing many compounds that like to spontaneously associate due to Brownian motion (random ubiquitous movement of tiny particles dispersed in fluids) and thus form structures of diverse diameters that leads to an unstable system.

The fact that turbidity is possible to visually observe is given by the Tyndall effect. The Tyndall effect describes a phenomenon when the light passing through a liquid medium is scattered by microscopic particles. And just the scattered light enables us to see the opalescence in a liquid from a slight haze up to strong turbidity (Kahle et al., 2020a; Siebert, 2009).

Based on particle size, turbidity is often divided into four groups:

- Large individual particles resulting from the coagulation of smaller particles, or after freezing and thawing the beer;
- Sediments formed by discrete particles of different sizes settling at the bottom of the vessel, such small sediments are often formed after pasteurization or during transport;

- Common turbidity - increases during beer storage, most of them are protein-polyphenol turbidity, less often polysaccharide, particle size 1-3 (up to 10) $\mu \mathrm{m}$;

- Invisible haze/ pseudo-haze - that means a presence of tiny particles smaller or just around $0.1 \mu \mathrm{m}$, the haze is invisible to the eye but measurable at $90^{\circ}$ since these particles cause significant light scattering.

\section{W. Bamforth gives a mildly different division} (Bamforth, 2011):

- Precipitates. Usually appears if the beer is exposed to extreme temperatures.

- Bits. The designation of bits means separate particles released from disintegrating precipitate. Bits are usually no longer associated with former precipitate but they are suspended in beer. Their presence is not as clear as it might seem. The recommended detection of bits is to filter beer using filter paper and stain the content on the paper with methylene blue. If we compare few papers to a different bulk of stained bits, we obtain semi-quantified results.

- Haze. Opacities are distinguished into two types:

- Chill haze/cold break - it appears when the beer is chilled to $0{ }^{\circ} \mathrm{C}$, however, the solution reclarifies when the beer is warmed to $20^{\circ} \mathrm{C}$;

- Permanent haze - opacity persisting in beer at all practical temperatures.

- Invisible haze. Although chill haze is reversible, it needs to be treated because over time it can become permanent. Chill haze is formed by aggregation of proteins, where hydrophobic and hydrogen bonds are involved and particle sizes range from 0.1 to $1.0 \mu \mathrm{m}$ (Kotlíková et al., 2013; Bamforth, 2011). The older the beer, the larger the particles of chill haze (Kotlíková et al., 2013). The permanent (irreversible) haze is based mainly on protein-polyphenol interactions and the particles have an irregular shape with a size ranging from 1 to $10 \mu \mathrm{m}$ (Kotlíková et al., 2013). While most haze active proteins, which show a high affinity to polyphenols, come from the hordein fraction of barley, the source of polyphenols is both, barley and hops. The cause of permanent haze development is the polymerization of polyphenols which can lead to covalent attachment to the phenolic moiety of the polypeptide chain (Teumer et al., 2019; Mastanjevic et al., 2018; Bamforth, 2011; Steiner et al., 2010a). 
Both types of haze represent a considerable problem for breweries. It is recommended to preferentially solve the issue of chill haze as it is a base of the latter permanent haze. Chill and permanent haze occurs in beer at $0{ }^{\circ} \mathrm{C}$ and can be measured together at this temperature as the socall total turbidity (Kotlíková et al., 2013).

\subsection{Causes of turbidity}

Turbidity in filtered and stabilized beer can be caused by a variety of phenomena (Siebert, 2009). The stabilization of colloids is all about how to prevent particles from aggregating or flocculating. In general, colloids may be stable either thermodynamically or kinetically (Chhabra and Basavaraj, 2019). It should be noted that beer is composed of many chemical substances with different character, most of them are hydrophilic, some of them carry an electric charge, and also hydrophobic substances are present. The electric charge of macromolecular substances plays an important role in beer stability. The particles with the same electrical charge are repelled that means the particle cannot aggregate, therefore this state helps to keep colloidal dispersion. However, once the particles lose their charge, they have an ideal opportunity to coagulate (Mastanjevic et al., 2018).

Particular attention should be paid to the following factors:

- Temperature is the main factor affecting turbidity formation just in several ways. A typical example is chill haze that occurs at the temperature around $0{ }^{\circ} \mathrm{C}$ and is probably related to further reduced solubility of hardly soluble substances. On the contrary, warming the beer to $20{ }^{\circ} \mathrm{C}$ typically disperses these types of haze. However, it should be noted that elevated temperature accelerates interactions among components that may form insoluble clusters and thus leads to massive development of turbidity (Siebert, 2009). We can summarize that beer should not be exposed particularly to temperature shocks, e.g. inadvertently frozen/heated during transport and storage. Furthermore, frequent temperature changes, usually in a distribution chain, initiate beer instability, which causes various defects of beer, including turbidity (Bamforth, 2011).

- $\quad \mathbf{H H}$ is well-known parameter that generally affects many phenomena and processes. In the case of beer, we take into account the effect on chemical, functional and visual properties. A typical example is proteins. $\mathrm{pH}$ value determines their real charge, the degree of ionization, solubility, space conformation, denaturation as well as enzymatic activity in some cases. The $\mathrm{pH}$ around $4.2-4.4$ is stated as the value promoting the formation of turbidity (Mastanjevic et al., 2018; Andres-Bello et al., 2013; Siebert, 2009). On the contrary, increasing $\mathrm{pH}$ brings a decrease of the haze formation (Siebert, 2009, 2006; Bamforth, 1999). Nevertheless, the typical pH for beer lies between $4.0-4.5$, i.e. in the range that most promotes turbidity formation.

- Oxygen is a well-known oxidation agent, i.e. the cause of oxidation reactions. After pitching wort, the presence of oxygen is undesirable in further production stages of beer. It may play a significant role in turbidity formation as well, e.g. polymerization of polyphenols is catalyzed by several enzymes including polyphenol oxidase and peroxidase or forming oxidized reactive forms of polyphenols and other substances (Mastanjevic et al., 2018; Kotlíková et al., 2013; Bamforth, 1999; Izawa et al., 1996; Šavel et al., 1996).

- Movement of beer. Colloidal instability may be promoted by prolonged shaking or agitation (Mastanjevic et al., 2018; Kotlíková et al., 2013; Speers et al., 2003). And even, the haze was associated with the beer motion on the shipboard during long transportation (Bamforth, 2016). An increased risk of turbidity formation is thought to be associated with easier aggregation of polymers (Speers et al., 2003).

- Aging is a natural chemical-physical process that is substantial for the theme of turbidity. Fresh conditions of young beer seem to protect them from observable opacity, however, as soon as a certain period is exceeded, haze formation starts and follows a roughly linear rate of development (Siebert, 2009; Speers et al., 2003).

- Ethanol concentration should only have a minor effect on the formation or prevention of turbidity according to scientific studies. Its semipolar character can cause reduced precipitation of polyphenols with proteins, nevertheless at the same time it cuts down the protein solubility (Siebert, 2009).

- Chemical substances - A separate chapter 2.4 Chemical composition of turbidity is devoted to this issue.

\subsection{Turbidity Origin}

We described and divided turbidity according to the particle size and its character, nevertheless, the crucial question for brewing practice is where turbidity particles come from. The following three options can be considered (Wainwright, 1974):

- Naturally occurring particles originating directly from chemical components of beer or raw materials;

- Procedural particles entering into beer during the brewing process, e.g. filtration and stabilization aids; 
- Contamination/foreign particles originating from the external environment, these are various mechanical impurities such as fiber, glass, etc. (Steiner et al., 2010; Glenister, 1975).

Turbidifiers originating from beer are frequently discussed in other places of this paper, therefore this part briefly deals with the extraneous material, for example filter and stabilizing aids, that can occur in beer and participate in the formation of turbidity. The presence of such foreign (in)organic materials in beer signalizes some errors in the process control (Kahle et al., 2020b). While this problem can be easily solved by post-filtration, residues stuck in containers (e.g. label residues) are difficult to prevent. Such material can appear in beer when a sudden fault emerges during bottle cleaning, or when problems with a container inspector occur.

Also, the residues of stabilizers such as PVPP or silica gel can enter into beer and affect its stability (Kahle et al., 2020a; Siebert, 2009).

The described causes of turbidity are fortunately not so frequent and usually have a solution such as using modern technology and equipment together with implementing common quality assurance, which on the other hand requires a noticeable investment.

However, at this point it is necessary to mention also the micro-plastic particles, which are widespread and burning issue in numerous industrial branches such as food and beverage products, but also clothing and many more. The micro-plastic particles are those with a size less than $5 \mathrm{~mm}$ in length entering the beer in various ways, e.g. from raw materials including water, during manual handling such as manual addition of additives, in the cellar, and of course from packaging material. Also subsequent contamination due to inappropriate sampling and treatment practice (Kahle et al., 2020b).

\subsection{Chemical composition of turbidity}

Beer is a very complex solution constituted of thousands components including macromolecules such as proteins, nucleic acids, polysaccharides, or lipids (Steiner et al., 2010). These macromolecular substances have different tendencies to interact/coagulate depending on the factors described above. This fact suggests that equally the chemical composition of turbidity is very diverse and largely determined by their origin (Bamforth, 1999).

The most common colloidal turbidity is proteinaceous, protein-polyphenolic nature together with polysaccharide (Teumer et al., 2019; Mastanjevic et al., 2018; Bamforth, 2011; Steiner et al., 2010). The approximate proportion is as follows: proteins range in between 14$77 \%$, polyphenols $15-75 \%$, and polysaccharides $1-14 \%$ (Kunz et al., 2012). Apart from these major haze active components, also metal ions, hop resins, or melanoidins should be considered in the case of colloidal instability of beer (Mastanjevic et al., 2018; Bamforth, 2011). It should be emphasized that the turbidity composed of only one pure component almost does not exist in practice, whereas the mixtures of below-discussed components commonly appear. For example, Leiper et al. (2003) found all proteins in their beer samples to be glycosylated to a varying degree, and the size of polypeptides occurring in glycosylated fraction varied in a relatively narrow range from 10 to $46 \mathrm{kDa}$.

Proteins. The proteinaceous material, including diverse (poly)peptides having molecular mass ranging from $<5$ to $>100 \mathrm{kDa}$, is present in beer in an approximate concentration of $500 \mathrm{mg} / \mathrm{L}$, whereas, mere $2 \mathrm{mg} / \mathrm{L}$ of proteins is enough to incite haze of $1 \mathrm{EBC}$ unit. Proteinaceous material originates mainly from barley and represents a part of the colloidal dispersion of beer. Several researchers have tried to find out what kind of proteins is haze active and whether there is a clear line between haze-active and foam-active proteins ( Jin et al., 2011; Evans et al., 2003). Although the results are still rather ambiguous, some conclusions can be generalized: Proteinaceous material in beer can be distinguished according to several criteria, e.g. (i) depending on whether some break down of proteins occurred during the brewing process and thus original intact proteins and pre-

Table 1 Basic classification of simple beer proteins according to solubility and their potential to form turbidity

\begin{tabular}{|l|c|c|c|c|}
\hline \multicolumn{1}{|c|}{ Proteins } & Solubility in & $\begin{array}{c}\text { Approx. molecular } \\
\text { weight (kDa) }\end{array}$ & Formation of turbidity & References \\
\hline Albumins & water, salt solutions & $\sim 70$ & partially & $\begin{array}{c}\text { Kotlíková et al., 2013; } \\
\text { Asano et al., 1982 }\end{array}$ \\
\hline Glutelins & alkaline solvents & $40-95$ & minimally & Kotlíková et al., 2013 \\
\hline Globulins & salt solutions & $26-300$ & $\begin{array}{c}\text { mainly } \beta \text {-globulin } \\
(\sim 100 \mathrm{kDa})\end{array}$ & Kotlíková et al., 2013 \\
\hline Prolamines/hordeins & $50-90 \%$ ethanol & $55-70$ & highly & $\begin{array}{c}\text { Kotlíková et al., 2013; } \\
\text { Jin et al., 2011; } \\
\text { Asano et al., 1982 }\end{array}$ \\
\hline
\end{tabular}


dominating cleavage products of these proteins can be differentiated (Steiner et al., 2010; Robinson et al., 2007; Bamforth, 1999) or (ii) based on affinity for water, we divide proteins into hydrophobic and hydrophilic (Bamforth, 2011; Apperson et al., 2002). Simple beer proteins can be divided into 4 basic groups according to relative molecular weight and solubility, namely albumins, glutelins, globulins, and prolamins (Table 1).

Table 1 shows that barley prolamine called hordein was found as one of the main haze-active proteins probably due to a large amount of proline (approx. 25\% mol) (Kahle et al., 2021, 2020a; Siebert, 2009). Typically, proteins rich in proline have been proved as very common contributors to haze formation (Steiner et al., 2010; Iimure et al., 2009; Leiper et al., 2003; Bamforth, 1999; Siebert, 1999; Siebert et al., 1996; Asano et al., 1982). This fact is probably related to the exceptional conformational rigidity of proline which affects the secondary structure of proteins as well as the way of hydrogen bond formation. Moreover, the hydrophobic character of proline offers the implementation of hydrophobic interactions that are similarly exploited in beer stabilization using PVPP (polyvinylpolypyrrolidone). All these special properties of proline allow to easily form complexes with polyphenols (Kahle et al., 2020a).

It is interesting to note that hordein also contains large amounts of glutamine next to proline (approx. $46 \%$ ) and that these amino acids are often located side by side in a proteinaceous chain. This specific location of proline and glutamine seems to contribute to remarkably strong polyphenol binding (Kahle et al., 2021; Siebert, 2009).

Polyphenols. Phenolic substances, i.e. the second major player in haze occurring, come from both barley (70-80\%) and hop (20-30\%). A greater influence on the formation of colloidal turbidity is attributed to the latter one. The polyphenol concentration ranges from 50 to $150 \mathrm{mg} / \mathrm{L}$ in stabilized lager beer and depends on raw materials as well as on the brewing practice (Kotlíková et al., 2013; Aron and Shellhammer, 2010).

The basic division of polyphenols into simple (two or more hydroxy groups attached to a single aromatic ring) and complex ones (multiple ring structures) is generally accepted. More details concerning polyphenol structure and properties are revied e.g. in Kotlíková et al. (2013), Callemien and Collin (2010) or Loch-Ahring et al. (2008). Those polyphenols participating in turbidity formation are typically flavan-3-ols (e.g. catechin, epicatechin, gallocatechin, and epigallocatechin) and its polymeric forms (proanthocyanidins) occurring as dimers, trimers, or polymers (e.g. procyanidin B3 composed of two catechin molecules or dimer prodelphini- din B3 consisting of catechin and gallocatechin molecule) (Kahle et al., 2021; Siebert, 2009; Loch-Ahring et al., 2008; McMurrough and Baert, 1994).

The flavan-3-ol monomers were found in permanent beer haze because they can bind to haze-active proteins. Loch-Ahring (2008) enumerated other monomeric substances that were detected in beer haze, these are phenolic acids (e.g. gallic or vanillic acid) and prenylflavonoids (like xanthohumol and isoxanthohumol). On the other hand, the polymeric proanthocyanidins offer two or more binding sites enabling them to cross-link proteins creating large structures (Kotlíková et al., 2013; Aron and Shellhammer, 2010; Loch-Ahring et al., 2008; McMurrough and Baert, 1994). It was found that proanthocyanidin dimers are most often involved in turbidity as higher oligomers are largely changed during the brewing process (Bamforth, 2011; Aron and Shellhammer, 2010). Also polyphenols with a higher number of hydroxyl groups on the aromatic ring show greater haze activity compared to less hydroxylated molecules. However, the position of hydroxyls on heterocyclic and aromatic rings has to be taken into account (Kotlíková et al., 2013; Aron and Shellhammer, 2010).

We can conclude that initially soluble complexes (e.g. oxidized flavanols participating in chill haze formation) can gradually grow to colloidal or larger size particles, which are the basis of either permanent colloidal haze or sediment. Sediment appears when the Brownian motion is not able to keep these particles in suspension. The protein/polyphenol ratio highly affects the amount of haze that can appear in beer. The greatest risk of massive turbidity impends when the ratio gets nearly 1 since the number of polyphenol binding ends corresponds to protein binding sites (Kahle et al., 2020a; Steiner et al., 2010; Siebert, 2009).

Polysaccharides, such as residual starch ( $\alpha$-glucans amylose or amylopectin), $\beta$-glucans, and arabinoxylans (pentosans) originating from malt or minor glycogen ( $\alpha$-glucan) coming from the yeast, as well as their degradation products together with natural oligosaccharides, impair the colloidal stability of beer and may contribute to visible turbidity (Kahle et al., 2020a; Teumer et al., 2019; Cai et al., 2016). The problem of malt polysaccharides can have two basic causes: either malt quality is unsatisfactory (enzyme equipment of malt), or a technological failure occurred (milling, insufficient enzymatic degradation during mashing, lautering). The occurrence of glycogen is related to complications in yeast management (Pahl, 2015).

Barley $\beta$-glucans dispersed in beer are well known for their formation of gelatinous aggregates that can clog filters. However, special filtration conditions such as mainly high pressure or sometimes elevated temper- 
ature may cause that these polysaccharides pass through the beer filters and aggregate later in packaged beer. If $\beta$-glucans do not form gelatinous particles, they at least cause increased invisible haze (Speers et al., 2003).

For example, $\beta$-glucans and arabinoxylans can be linked to polyphenols and proteins by hydrogen bonds into a more complicated structure (Kotlíková et al., 2013).

oxalate. Oxalic acid, which comes mostly from barley and slightly from hops, reacts together with calcium, usually originating from brewing water, to form calcium oxalate. Its solubility in beer is rather low and therefore it precipitates in the crystalline form. It may also be involved in the formation of the chill and permanent haze (Kahle et al., 2020a; Teumer et al., 2019). The content of oxalic acid in malt depends mainly on the growing and climatic conditions of a particular year (Pahl, 2015), typical values in beer are ranging from 4 to $32 \mathrm{mg} / \mathrm{L}$ (Masar et al., 2003).

Metals. Certain metals should be considered as promoting turbidity for the following reasons:

i) Catalytic effect of metal ions that supports oxidation reactions of the beer compounds (Kahle et al., 2020a; Aron and Shellhammer, 2010). For instance, iron in its ferrous state $\left(\mathrm{Fe}^{2+}\right)$ contributes to polymerization reactions of polyphenols (Kunz et al., 2012).

ii) Precipitating effect on proteins and polyphenols, thus metals support the transition of chill haze into permanent one ( Teumer et al., 2019; Mastanjevic et al., 2018).

The following metals were detected in beer turbidity: aluminum, barium, calcium, chromium, copper, iron, lead, magnesium, manganese, molybdenum, nickel, silver, strontium, tin, vanadium, and zinc (Aron and Shellhammer, 2010).

For example, magnesium or manganese including their salts were discovered in increased concentration in the residues of chill haze. While the metals such as aluminum, iron, nickel, copper, tin, and lead were identified in the residues of permanent opacity (Kotlíková et al., 2013).

Some metals such as copper, iron, and aluminum can occur in turbidity at several thousand-fold higher concentrations than in the initial beer as these metals are readily bound by phenolic, amino or, carboxyl groups (Aron and Shellhammer, 2010). The concentration of individual metals in beer turbidity is outlined in scheme 1 . The metals get into beer mainly from brewing water and used metal equipment (Kotlíková et al., 2013).

\section{Methods for turbidity identification - overview}

Countless analytical techniques using specialized instrumentation can be used to analyze turbidity composition, cause, and its origin, e.g. chromatographic (Loch-Ahring et al., 2008; Masar et al., 2003) and electrophoretic methods (Robinson et al., 2007; Masar et al., 2003), fluorescence spectroscopy (Sikorska et al., 2006; Apperson et al., 2002), atomic spectroscopy (Sohrabvandi et al., 2010) or immunological techniques (Robinson et al., 2007; Evans et al., 2003).

Most recently the usage of Raman spectroscopy was published, especially TI-RMS (Turbidity Identification Raman Micro-Spectroscopy) for the identification and differentiation of turbidity particles in a complex solution such as beer. RMS is based on inelastic interactions of light with chemical bonds of present substances resulting in wavelength changes known as Raman scattering. It means that monochromatic light of high intensity (usually emitted by a laser) interacts with specific molecular vibrations and consequently, the energy of laser photon shifts to a lower or higher level. In this way, the RMS provides unique chemical and structural information in the form of Raman spectra. Nevertheless, the immensely miscellaneous composition of beer is related to difficulties with RMS (i.e. high fluorescent noise, weak carbohydrate spectra, etc.). The authors showed and discussed the problems of the RMS application in beer tur-

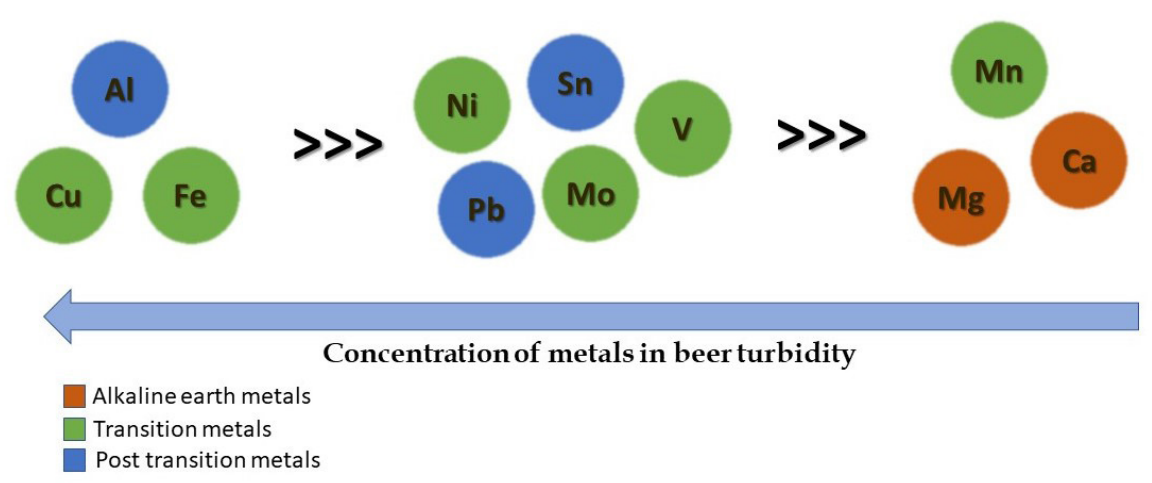

Scheme 1 Based on data from Aron and Shellhammer, 2010 
bidity analysis, presented several solutions how to cope with the appearing obstacles, and proposed the next possibilities of method optimization.

Although the analysis itself is fast and simple, the cost of the equipment is quite high, therefore this evolving method is particularly recommended for large laboratories that may use the RMS for multiple purposes (Kahle et al., 2021, 2020a, 2020b).

However, our article is focused on simple and low-cost methods that breweries can readily apply themselves with basic laboratory equipment, therefore, an overview of practical analytical and microscopic methods that enable the identification as well as the cause of turbidity is presented in the following text.

The methods used to identify turbidity can be divided into five basic groups:

- spectroscopic methods and particle size estimation;

- microscopic analysis and particle staining;

- chemical analysis;

- enzymatic treatment;

- identification of turbidity precursors.

Standardly, separation of the deposit from the liquid should be performed before the identification methods themselves. Centrifugation or membrane filtration is a commonly used procedure, however, a less widespread but very effective principle such as gel permeation chromatography (GPC) can be applied. This method enables to separate particles according to their molecular weight, and thus estimates their particle size. In brewing, it is a useful method for the identification of glucans, and assigns them to their origin (e.g. glycogen, amylopectin, etc.). Separated groups of glucans can be detected after staining with iodine using photometric analysis due to the formation of blue complexes (Kahle et al., 2020a; Steiner et al., 2011).

\subsection{Turbidity measurement using spectroscopic methods}

A great advantage of all techniques using spectroscopic methods is their non-destructive character, and thus they can be applied in in-line/on-line measurement.

The classical static light scattering methods provide information about particle sizes (Teumer et al., 2019).

Nephelometry. The principle of nephelometry lies in the Tyndall effect that in practice means measurement of the light scattering intensity caused by particles present in beer, the measurement usually being made perpendicularly to the incident beam. The intensity of scattered light depends on several variables counting the size, shape, and concentration of suspended particles, the angle at which the scattering is measured, the wavelength of light in relation to the particle diameter, and refractive indices of the particle and the solvent (Siebert, 2009). The haze or turbidity value is the quantitative statement of the qualitative phenomenon of turbidity. The haze value can be determined by either of two fundamentally different methods: determination of the decrease in the intensity of the transmitted light or determination of the intensity of the scattered light (EBC 9.29, 2015). In brewing practice, a measurement at two angles $90^{\circ}$ and $15^{\circ} / 25^{\circ}$ is used. The low angle value depends on a type of nephelometer (specifically on its light source); generally, the angle is ranging from $11^{\circ}$ to $25^{\circ}$ (Kahle et al., 2020a; Siebert, 2009; Bamforth, 1999; Mundy and Boley, 1999). The measurement at $90^{\circ}$ is particularly sensitive in the interval of tenths of $\mu \mathrm{m}$ up to approx. $3 \mu \mathrm{m}$ (common colloidal turbidity, carbohydrate turbidity). The size of turbidity measured at $15^{\circ} / 25^{\circ}$ is proportional to the particles with a dimension of several $\mu \mathrm{m}$ (larger colloidal particles, diatomaceous earth particles, PVPP, silica gels, and microbiological turbidity caused by bacteria and/or yeasts).

During beer aging, colloidal particles get bigger from submicron to over a micron-scale (Sladky et al., 2001). The ratio of $\mathrm{T} 15^{\circ} / \mathrm{T} 90^{\circ}$ should be in the range of 0.3 to 0.5 for well-filtered beer. A value higher than 0.7 indicates the presence of such big particles that probably filtration problems occur during beer filtration (Gabriel et al., 1994). Siebert (2000) reported that values between 0.38 to 0.82 present a visual haze threshold.

Turbidimetry is also a photometric method based on the attenuation of the incident (transmitted) radiation due to the scattering effect of suspended particles in the solution (beer) in a directly transmitted beam (i.e. detector is located at $180^{\circ}$ from the incident beam).

There are several protocols available for presented optical methods such as measurement according to beer analytic methods (EBC, MEBAK, ASBC, etc.). However, all protocols use the same calibration standard, i.e., formazin. The only difference is the use of diverse scales, e.g. one EBC Formazin Haze Unit (EBC u.) is equivalent to 69 ASBC Formazin Turbidity Units (FTU) (Speers et al., 2003).

The evaluation given in Table 2 is used to compare the results to the visual assessment (EBC 9.29, 2015). The EBC haze standard for brilliant beer of $0.5 \mathrm{EBC}$ is somewhat too stringent since visual detectable haze is in the vicinity of $0.70 \mathrm{EBC}$.

It should be still mentioned that optical methods have very limited ability to distinguish various types of turbidity. For this reason, the above-described measurement can be complemented with suitable staining, which is addressed in the next chapter 3.2. 


\subsection{Microscopic analysis and staining of turbidity particles}

Microscopic analysis is a basic step to identify turbidity and clarify its origin. Light microscopy usually determines unambiguously whether the cause of turbidity is microbiological, colloidal, or a combination thereof. This method is applicable for turbidity which is at least slightly visible to the naked eye. In addition to microbial cells such as yeast and bacteria, there can be detected particles with a regular shape (e.g. crystals) and also some irregular particles (e.g. diatomaceous earth, adsorbents). The common procedure is the following: An aliquot of a beer sample is centrifuged or filtered through a membrane filter. The obtained sediment is observed in a light microscope, most often at a magnification of 630x. It is advisable to use image analysis to measure the particle size and document it at the same time.

Microscopic and/or optical analysis can be combined with staining of turbidity particles to supplement information about the turbidity origin. This method is suc-
Table 2 Haze values (in EBC u.) vs. visual assessment

\begin{tabular}{|c|c|}
\hline EBC u. & Visual assessment \\
\hline$<0.5$ & brilliant \\
\hline $0.5-1.0$ & almost brilliant \\
\hline $1.0-2.0$ & very slightly hazy \\
\hline $2.0-4.0$ & slightly hazy \\
\hline $4.0-8.0$ & hazy \\
\hline$>8.0$ & very hazy \\
\hline
\end{tabular}

cessfully used for example for amorphous particle haze where the use of specific staining (colouring) can help to provide appropriate information (Siebert, 2009).

Thus, for example, the yellow eosin dye points to protein components that can be detected as pink-colored skins, flakes, ribbons, and fine grains (Kahle et al., 2020a). Thionine stains neutral polysaccharide compounds into purple.

Table 3 An overview of staining dyes and their use in detection of beer turbidity compound

\begin{tabular}{|c|c|c|c|}
\hline Staining dye & Compound/material & Detection colour & References \\
\hline \multirow[t]{5}{*}{ Yellow eosin } & Proteins & Pink & RIBM data \\
\hline & & Pinkish-orange & Kahle et al., 2020a \\
\hline & & Slightly pink & Steiner et al., 2010 \\
\hline & & $\begin{array}{l}\text { Depends on protein amount: } \\
\text { - lower amount - light pink } \\
\text { - higher amount - dark red }\end{array}$ & Niemsch and Heinrich, 2006 \\
\hline & PVPP & Red & Niemsch and Heinrich, 2006 \\
\hline \multirow[t]{4}{*}{ Thionine } & $\begin{array}{l}\text { Neutral polysaccharides } \\
\text { - e.g. starch, dextrins }\end{array}$ & Violet, pink & Kahle et al., 2020a \\
\hline & & Purple & RIBM data \\
\hline & & Blue-violet & Niemsch and Heinrich, 2006 \\
\hline & $\begin{array}{c}\text { Acidic polysaccharides } \\
\text { - e.g. arabic gum or alginates }\end{array}$ & Pink & Niemsch and Heinrich, 2006 \\
\hline \multirow[t]{3}{*}{ lodine } & Starch, higher dextrins & Blue-violet & $\begin{array}{c}\text { RIBM data; } \\
\text { Steiner et al., } 2011\end{array}$ \\
\hline & Lower dextrins & Orange & $\begin{array}{c}\text { RIBM data; } \\
\text { Steiner et al., } 2011\end{array}$ \\
\hline & PVPP & Strong orange & Kahle et al., 2020a \\
\hline \multirow[t]{2}{*}{$\begin{array}{l}\text { Schulze solution } \\
\text { (iodine solution } \\
\text { in zinc hypochlorite) }\end{array}$} & Starch grains & $\begin{array}{c}\text { Dark blue to black } \\
\text { depending on the amount }\end{array}$ & Niemsch and Heinrich, 2006 \\
\hline & Cellulose fibers & Blue & Niemsch and Heinrich, 2006 \\
\hline \multirow[t]{2}{*}{ Methylene blue } & Polyphenols, tannoids & Dark blue & RIBM data \\
\hline & Bits & Blue & Bamforth, 2016 \\
\hline Safranin & Filter aids based on bentonite & Red & Niemsch and Heinrich, 2006 \\
\hline Nile blue & Polypropylene glycol alginates & Dark blue** & Niemsch and Heinrich, 2006 \\
\hline Calcofluor* & $\beta$-Glucans & Fluorescent blue & $\begin{array}{l}\text { Kahle et al., 2020a; } \\
\text { Izawa et al., } 1996\end{array}$ \\
\hline Congo red* & $\beta$-Glucans & Red & Kahle et al., 2020a \\
\hline
\end{tabular}

* only fluorescence microscopy

** after alginate precipitation as a salt using acidic solution and calcium chloride 
Polyphenols and tannoids are dark-blue after staining with methylene blue. Starch and higher dextrins tints blue-violet and lower dextrins orange/red with iodine solution (Steiner et al., 2010). Iodine can be as well used to identify the PVPP particles, which show a strong orange colour.

If the laboratory has a possibility of fluorescent microscopy, other dyes can be used, e.g. Calcofluor or Congo red for $\beta$-glucans of both yeast or malt origin. While Calcofluor staining gives a fluorescent blue indication, Congo red tints $\beta$-glucans red (Kahle et al., 2020a). The other examples of staining dyes are listed in Table 3.

\subsection{Chemical analysis using dissolution}

Another possibility of identifying turbidity is its dissolution in lye or acid. For example, protein-polyphenol turbidity is dissolved in $2 \%$ sodium hydroxide solution, calcium oxalate, and also polysaccharides in $1 \%$ sulphuric acid solution (authors in-house method). Kahle in her review states a similar method that uses $1 \mathrm{M}$ potassium hydroxide solution which dissolves protein particles and $10 \%$ sulfuric acid for dissolution of calcium particles (Kahle et al., 2020a).

\subsection{Enzymatic treatment}

Enzyme analysis is useful for the characterization of biological particles especially if the substances are difficult to separate from each other (Teumer et al., 2019). The basic assumption of an enzymatic approach lies in a decrease of intensity of the original turbidity after enzymatic cleavage of the relevant macromolecular substance. First, the intensity of turbidity in an untreated sample is measured nephelometrically, and then the cloudy beer is incubated with an appropriate enzyme under suitable conditions for more than $12 \mathrm{~h}$. A lower intensity value in the subsequent measurement indicates the degradation of turbidity-active particles by the applied enzyme (Kahle et al., 2020a). For example, pepsin is used to degrade proteins, lichenase to degrade $\beta$-glucans, or amyloglucosidase to cleave starch and dextrins (Kahle et al., 2020a; Steiner et al., 2010). Amyloglucosidase serves as both an analytical tool and agent that can dissolve carbohydrate-based turbidity that usually points to a problem in the brewhouse during wort preparation. Other enzymes such as glucanase or mannanase can be used for the identification of poor quality of malt or draw attention to the problems in yeast management (Niemsch and Heinrich, 2006).

\subsection{Identification of possible turbidity precursors}

If turbidity of the beer is indistinct, previous procedures fail and it is necessary to estimate whether precursors and their concentration could endanger the stability of the analyzed beer (Bamforth, 1999). Within precursors of turbidity, the following ones are the most often determined:

- total polyphenolic substances (EBC 9.11, 2002), tanoids (MEBAK 2.16.3, 2013) or flavanoids (EBC 9.12, 1997);

- high molecular weight proteins - ammonium sulfate test (MEBAK 2.14.2.4, 2013), proteins with molecular weight over 5,000 Da (Bradford, 1976), magnesium sulfate precipitable proteins (MEBAK 2.6.3.1, 2013), and so-called sensitive tannin-precipitable proteins (EBC 9.40, 2012);

- oligo- and polysaccharides - alpha-glucans (Basařová, 1993), beta-glucans (EBC 9.31.2, 2008), total high molecular weight glucans (EBC 9.31.2, 2008), pentosans (arabinoxylans) (Basařová, 1993; Douglas, 1981), the so-called iodine value corresponding to the concentration of dextrins (MEBAK 2.3, 2013);

- oxalates (MEBAK 2.22.2, 2013); calcium (EBC 9.19, 2002).

\subsection{Prediction of colloidal stability}

The colloidal stability of beer limits its shelf life. Therefore, breweries are forced to prolong this period using stability-extending agents. Prediction of colloidal stability methods are used to verify the effectiveness of the stabilization process and few of them determine the minimal shelf life of beer. Beyond methods for the identification of turbidity precursors (see above), there are forcing and precipitation ones. Forcing methods accelerate the aging of beer through an alternation of high and low temperatures resulting in the earlier formation of colloidal haze. The principle of precipitation methods lies in a gradual addition of a selective precipitant to form turbidity. Consumption of reagent to reach a certain limit of haze corresponds to the shelf life.

Probably the most used forcing test is the heat forcing test where thermal treatment (alternation of the warm and cold period) accelerates haze formation. The principle of these tests is to accelerate the aging process. The cold period corresponds to temperatures close $0{ }^{\circ} \mathrm{C}$ and the warm period is ranging from 40 to $60{ }^{\circ} \mathrm{C}$ according to a variant of this method. The process is finished when haze is more than $2 \mathrm{EBC} u$. The prediction of stability is determined by the number of warm days before haze of $2 \mathrm{EBC} u$. is reached. One warm day corresponds to approximately 1 month of stability (Dienstbier et al., 2010). The measurement of the intensity of a beam of scattered light through the sample is done with angles of $90^{\circ}$ (side scattering) and of 11 to $25^{\circ}$ (forward scattering). 
Several variants of this method differ in the length and temperatures of the periods:

- $168 \mathrm{~h}\left(40^{\circ} \mathrm{C}\right)-24 \mathrm{~h}\left(0^{\circ} \mathrm{C}\right)-$ original EBC test

- $12 \mathrm{~h}\left(0^{\circ} \mathrm{C}\right)-48 \mathrm{~h}\left(60^{\circ} \mathrm{C}\right)-12 \mathrm{~h}\left(0^{\circ} \mathrm{C}\right)-$ actual EBC test $(\mathrm{EBC} 9.30,1997)$.

- $6 \mathrm{~h}\left(0^{\circ} \mathrm{C}\right)-16 \mathrm{~h}\left(66^{\circ} \mathrm{C}\right)-6 \mathrm{~h}\left(0^{\circ} \mathrm{C}\right)$ - test according to Basařová (1993).

- $168 \mathrm{~h}\left(60^{\circ} \mathrm{C}\right)-24 \mathrm{~h}\left(0{ }^{\circ} \mathrm{C}\right)-$ test according to Schild (Basařová, 1993).

- $24 \mathrm{~h}\left(0^{\circ} \mathrm{C}\right)-144 \mathrm{~h}\left(50^{\circ} \mathrm{C}\right)-24 \mathrm{~h}\left(0{ }^{\circ} \mathrm{C}\right)$ - test according to Šavel, 1992.

Precipitation tests are based on the precipitation of the haze forming precursors by a titration agent. The formation of turbidity is continuously monitored using a turbidity meter.

- Saturated Ammonium Sulphate Precipitation Limit - Beer is titrated by ammonium sulfate ( $45 \mathrm{~g}$ in $100 \mathrm{~mL}$ of water) until haze of $2 \mathrm{EBC} u$. Well stabilized beer has a consumption of sulfate $2.2 \mathrm{~mL}$ per $10 \mathrm{~mL}$ of beer, the consumption of sulfate for non-stabilized beer ranges from 1.0 to $1.5 \mathrm{~mL}$ per $10 \mathrm{~mL}$ of beer (Basařová, 1993).

- Determination of Sensitive Proteins - The determination of sensitive proteins in beer is performed by nephelometric measurement of turbidity after addition of tannic known quantity of tannic acid. The tannic acid combines with sensitive proteins in the beer and causes precipitation Sensitive proteins are calculated as subtraction of final turbidity of the beer after addition of 5 or $10 \mathrm{mg}$ of tannic acid per liter and initial turbidity of the beer (EBC 9.40, 2012).

- Formaldehyde Test - Tempered beer at $12{ }^{\circ} \mathrm{C}$ is spiked by $5 \mathrm{~mL}$ of $35 \%$ formaldehyde solution, the bottle is immediately closed and haze is measured. Subsequently, the beer bottle is placed in an ice-water bath for $24 \mathrm{~h}$, where haze is measured again. Then, the increase of turbidity is multiplied by a correction factor of 4.25 to obtain a probable shelf-life (Basařová, 1993).

\section{Methods for turbidity identification - examples from practice}

As new brewing technologies are developed and used, today's practice still brings new and sometimes very curious causes of turbidity. Therefore, each such a case requires a personal approach, in other words, it is not possible to generalize a uniform procedure for identifying turbidity or opalescence. Several not quite common examples including figure documentation and a pro- cedure of turbidity identification step by step will be demonstrated in the second part of this article. The routine assay used in our laboratory for more frequent cases is described in the following text.

The first step is centrifugation $(100 \mathrm{~mL}$ of a sample is centrifuged at 3,000 RPM for $30 \mathrm{~min}$ ), with a subsequent microscopic observation (630× magnification AXIOSKOP, Zeiss, recorded using Imaging Source DMK 23UX174 camera and documented by image analysis NIS Elements, ver. 5.10. for Windows 10, Laboratory Imaging).

Image analysis divides the origin of turbidity into microbiological, inorganic (kieselguhr, oxalates, and PVPP, or other particles), and colloidal turbidity. Typical examples of inorganic agents such as micro shards of glass, kieselguhr (fine and coarse), stabilization agents (PVPP, pearlite), rust, fibers from the filter plate, or paper fibers, are shown in Figures 1, 2, 3, 4, 5, and 6, respectively. Figure 7 shows typical free oxalate crystals.

Uncleaved starch grains which are shown in Figure 8 can be detected in beer when a wrong mashing procedure is used.

Colloidal turbidity is demonstrated in Figures 9 and 10. The particles forming colloidal turbidity are presented in Figure 9. Their size is very diverse, turbidity can be formed by miniature particles with a size of $0.5 \mu \mathrm{m}$ up to the visible particles. The association of microbiological and colloidal turbidity is given in Figure 10. Microbial impurity formed a nucleus where colloid started to precipitate.

When colloidal turbidity is determined, following suspension analysis using particle staining, or dissolution (see above) are applied. In most cases, subsequent chemical analysis of beer to determine turbidity precursors is necessary for more detailed information. However, the possibility of transition of some macromolecules (precursors) into precipitated turbidity must be taken into account when evaluating the results. Their concentration in the liquid phase is then lower than in reality.

The issue of turbidity concerns most lagers produced in industrial breweries where the critical parameters are the concentration of polyphenols, proteins with molecular weight over 5,000 Da, and polysaccharides. Based on our long-time results (unpublished data from RIBM), the uppermost parameter is the right content of proteins determined by the Bradford method (Bradford, 1976), which states that ideal for $12 \%$ lager ( $12 \%$ is original gravity) is the value of about $25 \mathrm{mg} / 100 \mathrm{~mL}$. A value up to $33 \mathrm{mg} / \mathrm{mL}$ signals a high probability of haze origin as peptides with molecular weights higher than 5,000 Da react very readily with polyphenolic compounds. The polyphenol content should be ideally under $150 \mathrm{mg} / \mathrm{L}$. However, if the concentration of proteins is below $33 \mathrm{mg} / \mathrm{mL}$, the concentration of polyphenols can be higher than $150 \mathrm{mg} / \mathrm{mL}$. 

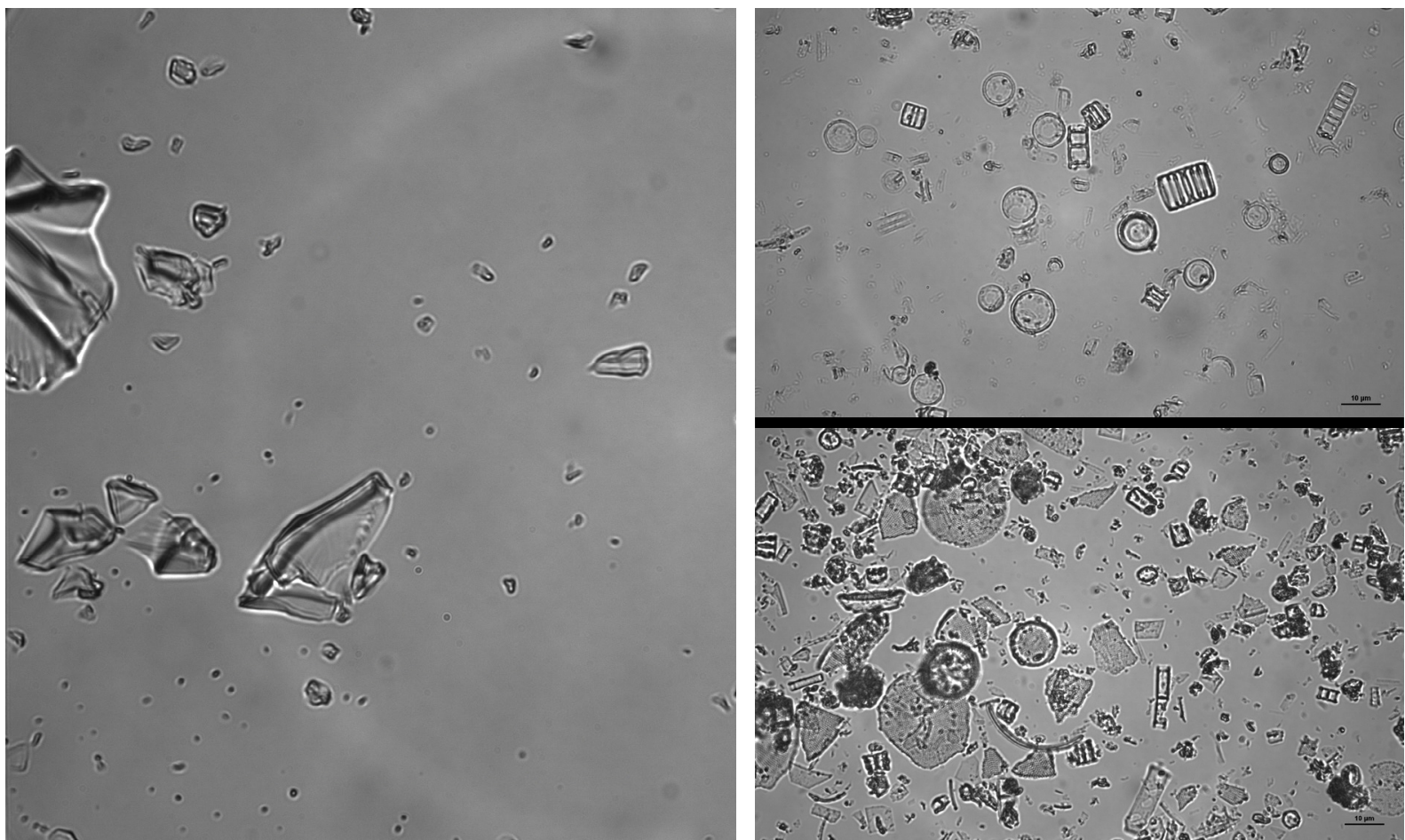

Figure 1 Micro shards of glass

Figure 2 Kieselguhr (fine and coarse)

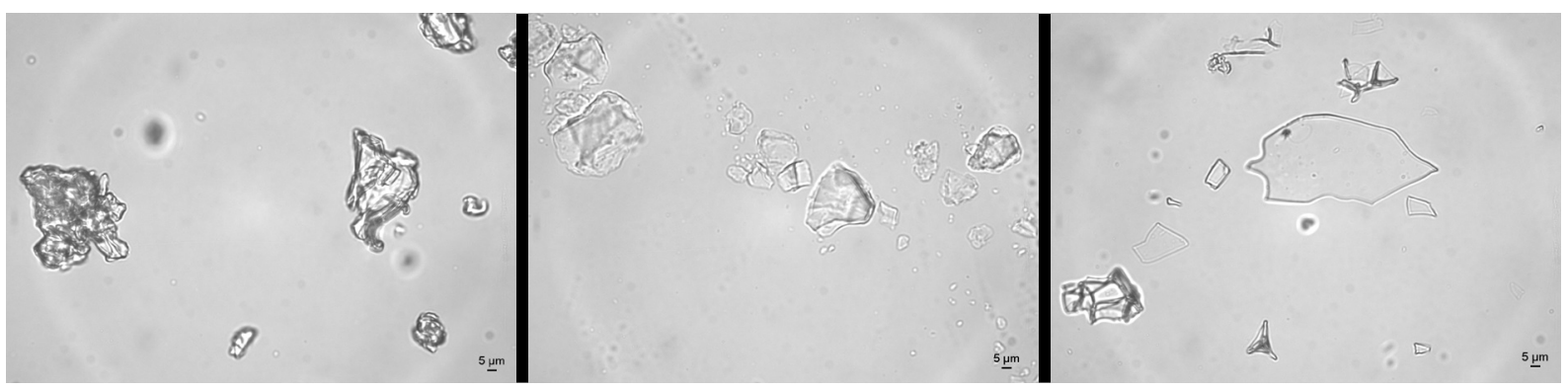

Figure 3 Stabilization agents (PVPP, pearlite)
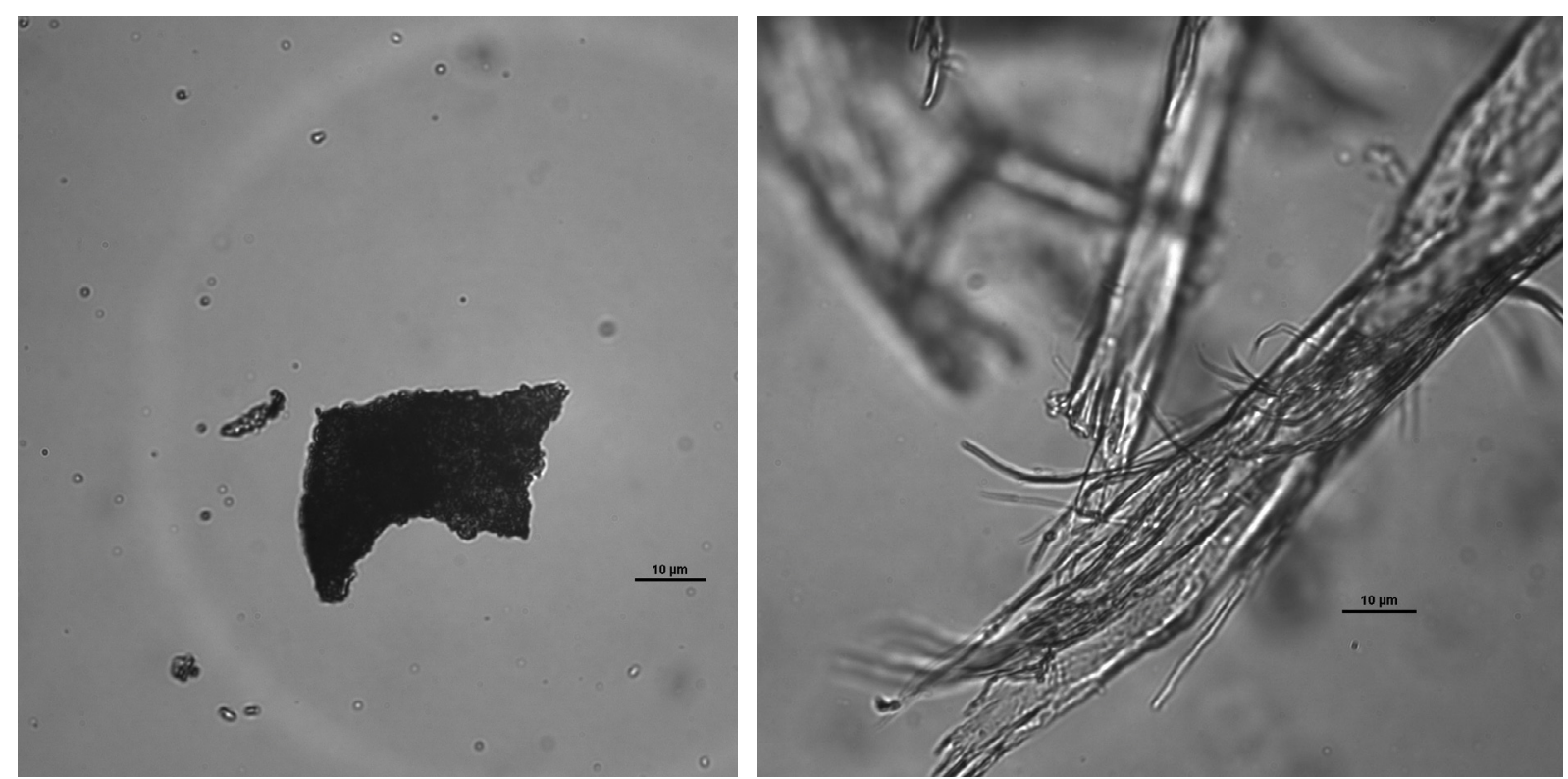


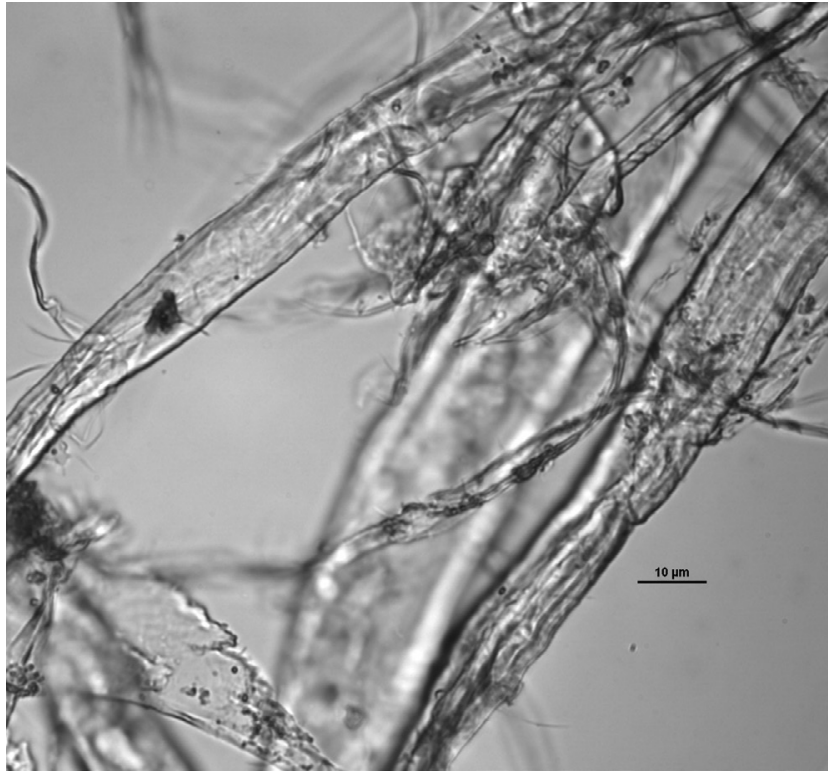

Figure 6 Paper fibers

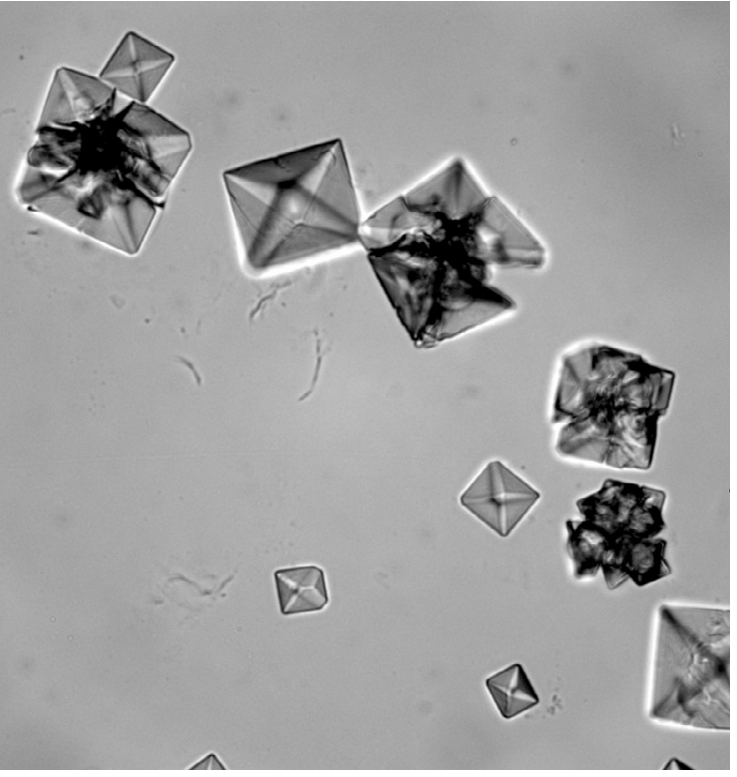

Figure 7 Oxalates

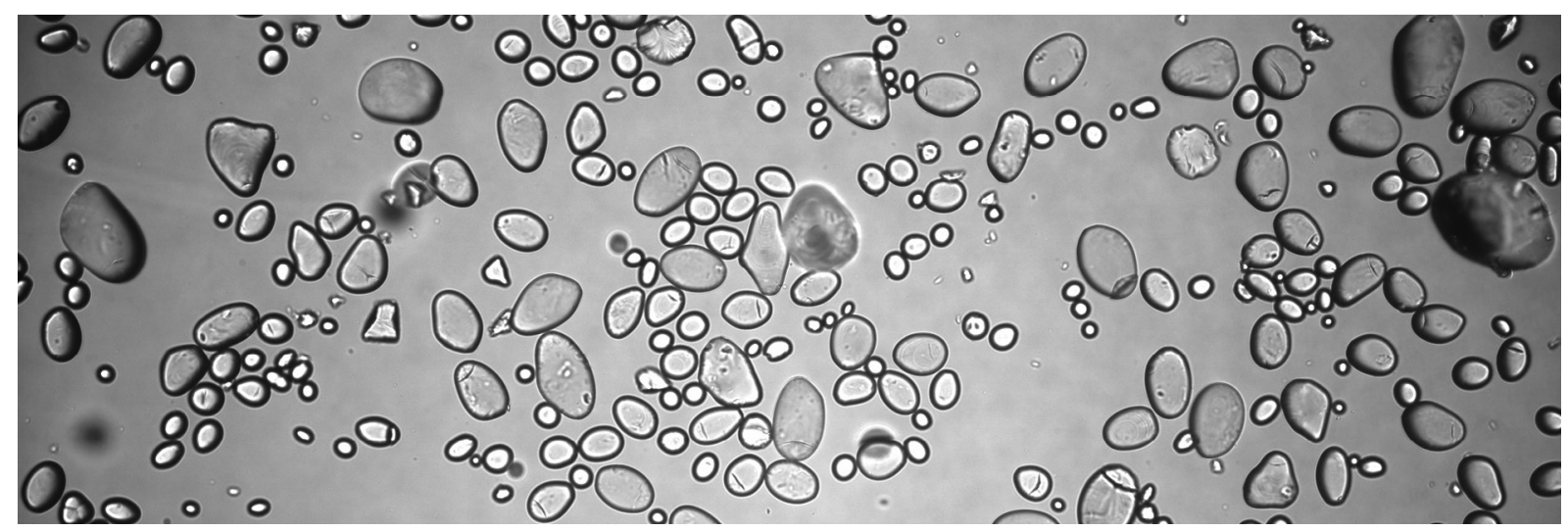

Figure 8 Starch grain

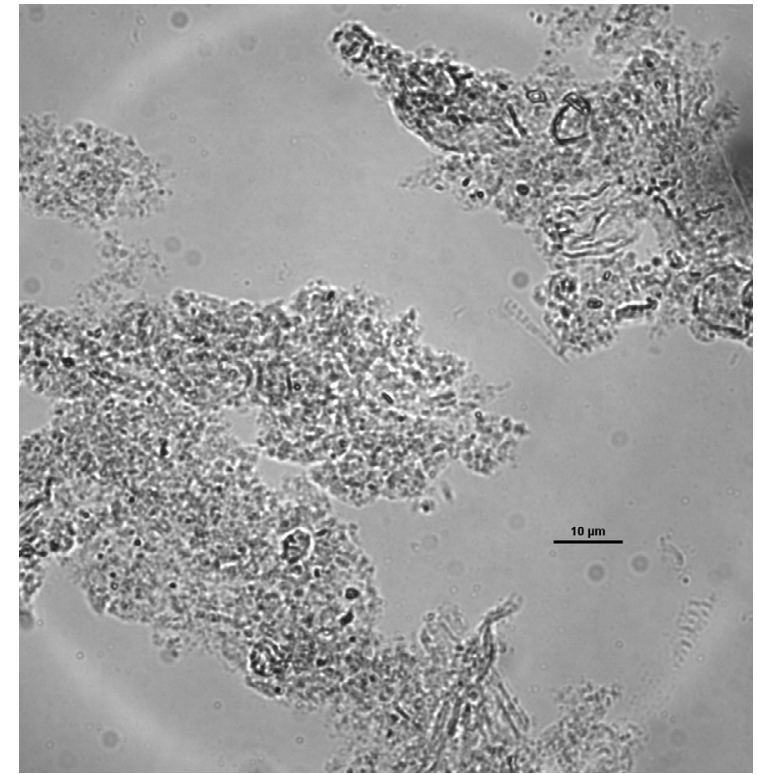

Figure 9 Colloidal turbidity formation from the miniature to visible particles

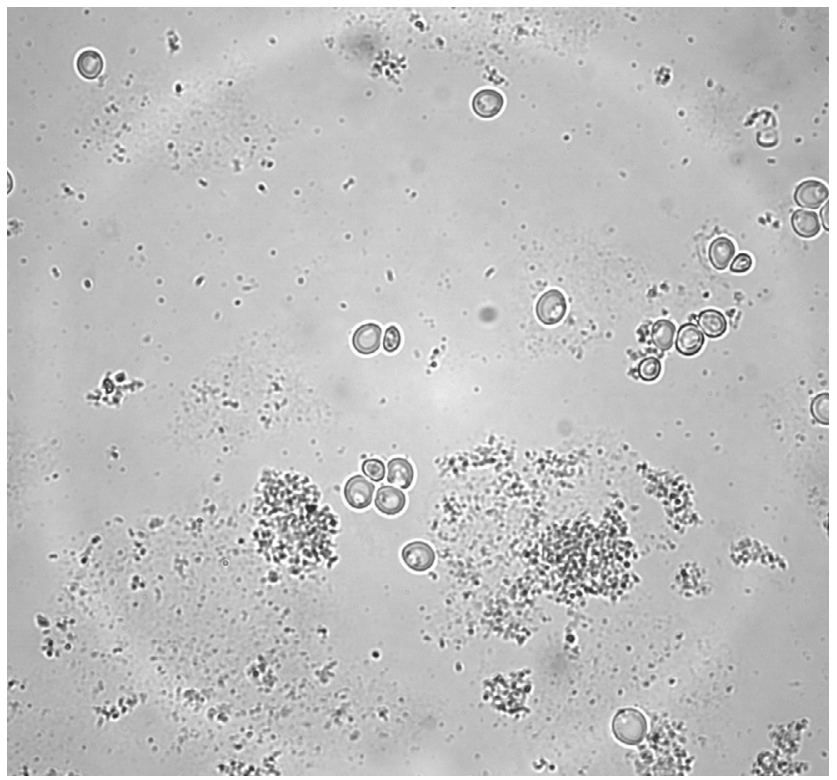

Figure 10 Association of microbial and colloidal turbidity 


\section{Conclusion}

Beer is inherent an unstable colloidal entity. Therefore, despite advanced filtration and stabilization procedures, turbidity formation and its identification in beer is still a hot topic for breweries as clarity and transparency of beer gives the first visual impression of the product quality to the customer. To establish and maintain a brand appeal, brewers have to satisfy consumer's expectations of high-quality product and among other, to ensure colloidal stability for the whole shelf life. Therefore, it is necessary to have enough of comprehensive knowledge supplemented with reliable analytical tool(s). This semi-review paper deals with non-microbiological turbidity in beer, including its chemical composition, the probable mechanisms of origin, together with factors that significantly affect the process of turbidity formation. An integral part is a coherent overview of methods applicable directly in breweries that enable to identify turbidity as well as infer on the origin. Typical examples of turbidity are demonstrated. In the subsequent part of this article, we will show and describe uncommon but significant cases from praxes.

\section{Acknowledgement}

This study was supported by the Ministry of Agriculture of the Czech Republic within the institutional support No. MZE-R01918

\section{References}

Andres-Bello, A., Barreto-Palacios, V., Garcia-Segovia, P., Mir-Bel, J., Martinez-Monzo, J. (2013). Effect of pH on color and texture of food products. Food Engineering Reviews, 5(3), 158-170. https://doi. org/10.1007/s12393-013-9067-2

Apperson, K., Leiper, K., McKeown, I., Birch, D. (2002). Beer fluorescence and the isolation, characterisation and silica adsorption of haze-active beer proteins. Journal of the Institute of Brewing, 108(2), 193199. https://doi.org/10.1002/j.2050-0416.2002.tb00540.x

Aron, P. M., Shellhammer, T. H. (2010). A discussion of polyphenols in beer physical and flavour stability. Journal of the Institute of Brewing, 116(4), 369-380. https://doi.org/10.1002/j.2050-0416.2010. tb00788.x

Asano, K., Shinagawa, K., Hashimoto, N. (1982). Characterization of haze-forming proteins of beer and their roles in chill haze formation. Journal of the American Society of Brewing Chemists, 40(4), 147154. https://doi.org/10.1094/ASBCJ-40-0147

Bamforth, C. W. (1999). Beer haze. Journal of the American Society of Brewing Chemists, 57(3), 81-90.

Bamforth, C. W. (2011). 125th Anniversary review: The non-biological instability of beer. Journal of the Institute of Brewing, 117(4), 488-497. https://doi.org/10.1002/j.2050-0416.2011.tb00496.x

Bamforth, C. W. (2016). Chapter 12 - Haze Measurement. In: Charles W.
Bamforth (Ed.), Brewing Materials and Processes (pp. 251-256). San Diego: Academic Press. https://doi.org/10.1016/B978-0-12799954-8.00012-5

Basařová, G. (1993). Pivovarsko-sladařská analytika. Praha: Merkanta.

Bradford, M. M. (1976). A rapid and sensitive method for the quantitation of microgram quantities of protein utilizing the principle of protein-dye binding. Analytical Biochemistry, 72, 248-254. https://doi. org/10.1006/abio.1976.9999

Cai, G., Li, X., Zhang, C., Zhang, M., Lu, J. (2016). Dextrin as the main turbidity components in wort produced from major malting barley cultivars of Jiangsu province in China. Journal of the Institute of Brewing, 122(3), 543-546. https://doi.org/10.1002/jib.356

Callemien, D., Collin, S. (2010). Structure, organoleptic properties, quantification methods, and stability of phenolic compounds in beer-a review. Food Reviews International, 26(1), 1-84. https://doi. org/10.1080/87559120903157954

Chhabra, R., Basavaraj, M. G. (Eds.). (2019). Chapter 13 - Colloidal dispersions. In: Coulson and Richardson's Chemical Engineering (Sixth Edition) (Sixth Edition, pp. 693-737). Butterworth-Heinemann. https://doi.org/10.1016/B978-0-08-101098-3.00014-7

Dienstbier, M., Jankova, L., Sladky, P., Dostalek, P. (2010). Methods for prediction of beer colloidal stability. Chemicke Listy, 104(2), 86-92.

DIN EN ISO 7027-1 (2016). Water quality - Determination of turbidity - Part 1: Quantitative methods, Pub. L. No. DIN EN ISO 7027-1, 9. Retrieved from https://www.iso.org/standard/62801.html

Douglas, S.G. (1981). A rapid method for the determination of pentosans in wheat flour. Food Chemistry, 7(2), 139-145. https://doi. org/10.1016/0308-8146(81)90059-5

EBC 9.11. (2002). Analytica EBC. Total Polyphenols in Beer by Spectrophotometry. Fachverlag Hans Carl, Nürnberg. Retrieved from https://brewup.eu/ebc-analytica

EBC 9.12. (1997). Analytica EBC. Flavanoids in Beer by Spectrophotometry. Fachverlag Hans Carl, Nürnberg. Retrieved from https://brewup. eu/ebc-analytica

EBC 9.19. (2002). Analytica EBC. Calcium in Beer by Atomic Absorption Spectrophotometry. Fachverlag Hans Carl, Nürnberg. Retrieved from https://brewup.eu/ebc-analytica

EBC 9.29. (2015). Analytica EBC. Haze in Beer: Calibration of Haze Meters. Fachverlag Hans Carl, Nürnberg. Retrieved from https://brewup.eu/ ebc-analytica

EBC 9.30. (1997). Analytica EBC. Prediction of Shelf-life of Beer. Fachverlag Hans Carl, Nürnberg. Retrieved from https://brewup.eu/ebc-analytica

EBC 9.31.2. (2008). Analytica EBC. High Molecular Weight $\beta$-Glucan Content of Beer: Fluorimetric Method. Fachverlag Hans Carl, Nürnberg. Retrieved from https://brewup.eu/ebc-analytica

EBC 9.40. (2012). Sensitive Proteins in Beer by Nephelometry. In Analytica-EBC. Nürnberg, Germany: Fachverlag Hans Carl. Retrieved from https://brewup.eu/ebc-analytica

Evans, D., Robinson, L., Sheehan, M., Tolhurst, R., Hill, A., Skerritt, J., Barr, A. (2003). Application of immunological methods to differentiate between foam-positive and haze-active proteins originating from malt. Journal of the American Society of Brewing Chemists, 61(2), 55-62.

Gabriel, P., Dienstbier, M., Sladky, P., Cerny, L. (1994). Vyuziti dvouuhloveho zakalomeru k rozliseni typu nekterych zakalotvornych castic. Kvasny prumysl, 40(7), 203-207. https://doi.org/10.18832/kp1994015

Glenister, P. R. (1975). Beer deposits: a laboratory guide and pictorial atlas for the study of the various particles found in the deposits of beer and ale. Miles Laboratories, Chicago. IL, USA.

Iimure, T., Nankaku, N., Watanabe-Sugimoto, M., Hirota, N., Tiansu, Z., Kihara, M., ... Sato, K. (2009). Identification of novel haze-active beer proteins by proteome analysis. Journal of Cereal Science, 49(1), 141147. https://doi.org/10.1016/j.jcs.2008.08.004 
Izawa, M., Takashio, M., Tamaki, T. (1996). Determination of high molecular weight beta-glucan in wort and beer using a post-column calcofluor flow-injection-analysis (FIA). Journal of the Institute of Brewing, 102(3), 183-189. https://doi.org/10.1002/j.2050-0416.1996.tb00907.x

Jin, B., Li, L., Feng, Z.-C., Li, B., Liu, G.-Q., Zhu, Y.-K. (2011). Investigation of hordeins during brewing and their influence on beer haze by proteome analysis. Journal of Food Biochemistry, 35(5), 1522-1527. https://doi.org/10.1111/j.1745-4514.2010.00474.x

Kahle, E.-M., Zarnkow, M., Jacob, F. (2020a). Beer turbidity Part 1: A review of factors and solutions. Journal of the American Society of Brewing Chemists, 1-16. https://doi.org/10.1080/03610470.2020.1803468

Kahle, E.-M., Zarnkow, M., Jacob, F. (2020b). Identification and differentiation of haze substances using Raman microspectroscopy. Journal of the Institute of Brewing, 126(4), 362-370. https://doi.org/10.1002/ jib.627

Kahle, E.-M., Zarnkow, M., Jacob, F. (2021). Beer turbidity Part 2: A review of Raman spectroscopy and possible future use for beer turbidity analysis. Journal of the American Society of Brewing Chemists, 79(2), 115-137. https://doi.org/10.1080/03610470.2020.1800345

Kotlíková, B., Jelínek, L., Karabín, M., Dostálek, P. (2013). Precursors and formation of colloidal haze in beer. Chemical Papers, 107, 362-368.

Kunz, Th., Chesnokova, A., Wietstock, P., Lutsky, V., Methner, F.-J. (2012). Acylphloroglucinol glucoside from hops: isolation, identification and haze-activity. Brewing Science, 65(7-8), 65-71.

Leiper, K. A., Stewart, G. G., McKeown, I. P. (2003). Beer polypeptides and silica gel part I. Polypeptides involved in haze formation. Journal of the Institute of Brewing, 109(1), 57-72. https://doi. org/10.1002/j.2050-0416.2003.tb00594.x

Loch-Ahring, S., Decker, F., Robbert, S., Andersson, J. T. (2008). Chill-haze - identification and determination of haze-active constituents by HPLC and mass spectrometry. Brewing Science, 61(3-4), 32-48.

Masar, M., Zuborova, M., Kaniansky, D., Stanislawski, B. (2003). Determination of oxalate in beer by zone electrophoresis on a chip with conductivity detection. Journal of Separation Science, 26(8), 647-652. https://doi.org/10.1002/jssc.200301375

Mastanjevic, K., Krstanovic, V., Lukinac, J., Jukic, M., Vulin, Z., Mastanjevic, K. (2018). Beer - the importance of colloidal stability (non-biological haze). Fermantation, 4(4). https://doi.org/10.3390/fermentation4040091

McMurrough, I., Baert, T. (1994). Identification of proanthocyanidins in beer and their direct measurement with a dual electrode electrochemical detector. Journal of the Institute of Brewing, 100(6), 409416. https://doi.org/10.1002/j.2050-0416.1994.tb00839.x

MEBAK 2.3. (2013). Photometric Iodine Test. In: J. Fritz (Ed.), MEBAK - Wort, Beer, Beer-based Beverages. Germany: Freising-Weihenstephan.

MEBAK 2.6.3.1. (2013). Precipitation with Magnesium Sulfate. In: J. Fritz (Ed.), MEBAK - Wort, Beer, Beer-based Beverages. Germany: Freising-Weihenstephan.

MEBAK 2.14.2.4. (2013). Precipitation with Ammonium Sulfate. In: J. Fritz (Ed.), MEBAK - Wort, Beer, Beer-based Beverages. Germany: Freising-Weihenstephan.

MEBAK 2.16.3. (2013). Tannoids. In: J. Fritz (Ed.), MEBAK - Wort, Beer, Beer-based Beverages. Germany: Freising-Weihenstephan.

MEBAK 2.22.2. (2013). Oxalate by Ion Chromatography with Conductivity detection. In: J. Fritz (Ed.), MEBAK - Wort, Beer, Beer-based Beverages. Germany: Freising-Weihenstephan.

Mundy, A., Boley, N. (1999). A survey of instrumentation used for the determination of haze in beer. Journal of the Institute of Brewing, 105(2), 75-78. https://doi.org/10.1002/j.2050-0416.1999.tb00008.x
Niemsch, K., Heinrich, T. (2006). Current problems of colloidal haze of beer. Kvasny prumysl, 52(1), 7-8. https://doi.org/10.18832/kp2006033

Pahl, R. (2015). Beer Turbidity: Reasons, Analytics and Avoidance. Presented at the Craft Brewers Conference, Portland, Oregon: VLB Berlin. Retrieved from http://www.craftbrewersconference.com/ wp-content/uploads/2015_presentations/R1320_Roland_Pahl.pdf

Robinson, L. H., Healy, P., Stewart, D. C., Eglinton, J. K., Ford, C. M., Evans, D. E. (2007). The identification of a barley haze active protein that influences beer haze stability: The genetic basis of a barley malt haze active protein. Journal of Cereal Science, 45(3), 335-342. https:// doi.org/10.1016/j.jcs.2006.08.013

Šavel, J., Zvihalová, D., Prokopová, M. (1996). Rychle stanoveni zakalotvornych latek piva. Kvasny Prumysl, 42(1), 11-15. https://doi. org/10.18832/kp1996001

Šavel, J., Prokopová, M. (1992). Jak volit teplotní šokování. Kvasny prumysl, 38(10), 290-292. https://doi.org/10.18832/kp1992027

Siebert. (2009). Haze in beverages. In: Taylor, SL (Ed.), Advances in Food and Nutrition Research, Vol. 57 (Vol. 57, pp. 53-86). https://doi. org/10.1016/S1043-4526(09)57002-7

Siebert, Carrasco, A., Lynn, P. (1996). Formation of protein-polyphenol haze in beverages. Journal of Agricultural and Food Chemistry, 44(8), 1997-2005. https://doi.org/10.1021/jf950716r

Siebert, K. J. (1999). Effects of protein-polyphenol interactions on beverage haze, stabilization and analysis. Journal of Agricultural and Food Chemistry, 47(2), 353-362. https://doi.org/10.1021/jf980703o

Siebert, K.J. (2000). Relationship of particle size to light scattering. Journal of the American Society of Brewing Chemists, 58(3), 97-100. https://doi.org/10.1094/ASBCJ-58-0097

Siebert, K. J. (2006). Haze formation in beverages. LWT-Food Science and Technology, 39(9), 987-994. https://doi.org/10.1016/j. lwt.2006.02.012

Sikorska, E., Gorecki, T., Khmelinskii, I., Sikorski, M., De Keukeleire, D. (2006). Monitoring beer during storage by fluorescence spectroscopy. Food Chemistry, 96(4), 632-639. https://doi.org/10.1016/j. foodchem.2005.02.045

Sladky, P., Cisarova, H., Dienstbier, M., Gabriel, P. (2001). Vyvoj koloidnich zakalu svetleho lezaku behem starnuti. Kvasny Prumysl, 47(11), 322-327. https://doi.org/10.18832/kp2001024

Sohrabvandi, S., Mousavi, S. M., Razavi, S. H., Mortazavian, A. M. (2010). Application of advanced instrumental techniques for analysis of physical and physicochemical properties of beer: A review. International Journal of Food Properties, 13(4), 744-759. https://doi. org/10.1080/10942910902818145

Speers, R., Jin, Y., Paulson, A., Stewart, R. (2003). Effects of beta-glucan, shearing and environmental factors on the turbidity of wort and beer. Journal of the Institute of Brewing, 109(3), 236-244. https:// doi.org/10.1002/j.2050-0416.2003.tb00164.x

Steiner, E., Arendt, E. K., Gastl, M., Becker, T. (2011). Influence of the malting parameters on the haze formation of beer after filtration. European Food Research and Technology, 233(4), 587-597. https://doi. org/10.1007/s00217-011-1547-0

Steiner, E., Becker, T., Gastl, M. (2010). Turbidity and haze formation in beer - insights and overview. Journal of the Institute of Brewing, 116(4), 360-368. https://doi.org/10.1002/j.2050-0416.2010. tb00787.x

Teumer, T., Raedle, M., Methner, F.-J. (2019). Possibility of monitoring beer haze with static light scattering, a theoretical background. Brewing Science, 72(7-8), 132-140. https://doi.org/10.23763/BrSc19-15teumer

Wainwright, T. (1974). Nonbiological hazes and precipitates in beer. Brewer's Dig., 49(5), 38-48. 